\title{
Women in Arms: Amazons in 17th Century English Drama
}

\author{
By Margarete Rubik
}

\begin{abstract}
This paper investigates the portrayal of Amazons in a variety of seventeenth century English plays. Sword women combining male connoted aggression and female beauty functioned as a female dream of empowerment as well as a misogynist nightmare. Hence the image of such 'masculine' women was mutable and could assume a number of different characteristics: Amazons could be portrayed as chivalrous and cruel, glamorous or denaturalized, chaste or lecherous. Humourous pictures of martial women exist side by side with hostile ones attacking the unruliness and insubordination of women and their lust for men. The fate of Amazons in seventeenth century drama is generally either death on the battlefield or marriage and submission to patriarchal rules. There are a few rare examples of dutiful wives still combining marital and martial virtues, but more often these female warriors only lay down their arms at the end of a play, out of love. Despite their prowess, the women always lose the single combat with a worthy male antagonist - usually the very man they love. In the central, sensual moment of revelation, the woman's helmet falls off and her hair falls loose. In plays featuring women in male disguise, the relationship between the lovers is often charged with homoerotic overtones: the hero is passionately attracted to the supposed boy-soldier. Androgynous figures like the Amazons also raise the question whether femininity and masculinity are inborn qualities or the products of education. As will be shown, $17^{\text {th }}$ century attitudes to the problem are ambiguous.
\end{abstract}

For centuries, Amazons have exerted a powerful fascination on our imagination and are part of the European literary landscape. (Davis, 1991, 190). But what, exactly, is an Amazon? The Encyclopedia of Amazons defines her as 'a huntress, warrior, duelist, or signal athlete' (Salmonson, 1991, xii), a sword woman who evinces a skill in combat similar to that of a man, whose aggression, as Shepherd $(1981,8)$ emphasizes, is not 'worn as a disguise', to be put on and off with her battle gear, but is something 'inner' ingrained in her personality. A figure occupying a 'middle ground' between woman and warrior (Shepherd, 1981, 9) and combining male connoted aggression and female beauty, the Amazon has functioned as a female dream of empowerment as well as a titillating male sexual fantasy or misogynist nightmare of a creature 'half

${ }^{*}$ Professor, University of Vienna, Austria. 
Fish half Flesh' (Hopkins, 1696, Act 4, Scene 1), which 'nature hath brought forth to mocke the sex of woman' (Dekker \& Middleton, 1611, Act 1, Scene 1). Hence the image of such 'masculine' women was mutable and could assume a number of different characteristics: Amazons could be portrayed as chivalrous or cruel, glamorous or threatening, man haters or sexual aggressors (Salmonson, 1991, xii; x).

Shepherd claims that there was a change in the characterization of Amazons from the Elizabethan period to the $17^{\text {th }}$ century, from chaste and exotic to lecherous and insubordinate, a threat to the social order. If we survey the drama from the middle to the end of the century, however, we will see that both stereotypes - that of the brave and admirable warrior and that of the denaturalised man-woman exist side by side. ${ }^{1}$ Combining this double vision, in Heywood's Iron Age (1632) for instance, the heroic Queen of Amazons Penthisilea, fighting on the side of the Trojans, is several times called a 'whore' (e.g. Heywood, 1632, Act 2, Scene 1) by her Greek antagonist.

A memorable example of an Amazon without any blemish is Victoria in Bell in Campo (1662), a victorious female general, conceived by Margaret Cavendish as a fantasy of female empowerment. Victoria accompanies her husband into war, raises a female army, wins a number of battles while the battalions of male soldiers are defeated, but willingly leaves the spoils of war to the men, once they have apologized for their earlier distrust of female prowess and fighting skills. In fact, the play goes out of the way to show that women are better warriors and strategians than men. In the end, Victoria enters the city in triumph dressed like a male conqueror and wins a number of royal privileges for the female sex, which, however, pertain mainly to the domestic sphere (Salmonson, 1991, 175). She is one of the few Amazonian figures who combine marital and martial virtues. There is no conflict between her role as loving wife and female generaless; her engagement in war does not impinge on her chaste femininity. Most other heroines, we shall see, are forced to decide for one role or the other.

Such an idealized image can also be occasionally found in men's plays, for instance D'Avenant's The Siege of Rhodes (first performed in 1656). Ianthe wants to share the hardships of war with her husband and commands the admiration even of the Turkish enemies, since in battle she is 'Fairer than Woman, and than man more fierce.' (D'Avenant, 1663, 38) In addition, she is commended for her chastity and loyalty towards her husband and the besieged citizens of Rhodes, a rare specimen of an Amazon and a loving wife all in one.

Derek Hughes claims that in the warrior society of Restoration drama, the 'key to power' is the 'capacity for violence' $(2004,34 ; 35)$ inherent in most men, but this is not true for women. The fate of Amazons in seventeenth century drama is generally either death on the battlefield or marriage and submission to patriarchal rules. It is characteristic that despite their prowess they generally lose a combat with a worthy male antagonist. Like Penthesilea in Heywood's tragedy, Rosalind, Hannibal's mistress, is slain in battle in Lee's Sophonisba

${ }^{1}$ Reproductions in Dixon's study (2002) show that baroque paintings of Judith beheading Holofernes also mingle wily seductiveness with heroism. 
(1676), as is Philarmia in Fane's The Sacrifice (1689), who rushes into the thick of fighting when she believes her lover to be dead.

Then strait like Lightning, Arm'd with bright Destruction, [she] Flew in the thickest Troops, and flash'd, and Shin'd, Struck dead whole Ranks before her; till she was

Extinguish'd by some Envious hand [...] (Act 5, Scene 1)

In tragicomedies, of course, the heroines revive even when mortally wounded, only to abdicate from their power for the sake of love. In Settle's Conquest of China by the Tartars (1676) the patriotic heroine, to complicate matters, is secretly in love with the enemy prince. Nonetheless, she fights heroically to defend her country, leaving heaps of dead on the battlefield in her wake, but loses the single combat with the beloved prince which is to decide upon the outcome of the war. The armed confrontation with the male lover is a set tableau in Amazonian plays and the climax of a female warrior's career (Shepherd, 1981, 12). Frequently, at the central, sensual moment of revelation, her helmet falls off and her hair falls loose. The Prince of the Tartars in Settle's tragicomedy is ashamed of having fought against and killed a woman in male disguise - but as befits the genre, the Amazon, in the end, is 'to Life, to Health, to Love restored' (1676, Act 5, Scene 2). A similar plot device is used in Hopkins' Friendship Improv'd, or The Female Warriour (1700), in which the eponymous heroine again seems fated to engage in a duel with the man she loves, but loosens her robes and lets her helmet drop before he actually draws on her. Henceforth, she bids adieu to fighting.

The same motif is used in Behn's The Young King, published 1683 but probably written in the late 1660s, where an Amazon bred for war is also softened by the power of love. Cleomena, too, is defeated by the enemy prince, who is, in reality, the man who wooed and won her in disguise, but she later stabs him because she believes he killed her lover, who has unaccountably disappeared. In the end, all misunderstandings are cleared up, all wounds are healed, and, stereotypically, 'the God of Love o'recomes the God of War' (1683, Act 5, Scene 4).

This sudden conversion to domesticity is particularly abrupt in Howard's The Womens Conquest (1670, printed 1671), where the Amazonian queen, a consummate warrior and strategian and also a merciful ruler combining both masculine and feminine virtues, is in the end suddenly smitten with love for a man she paid no attention to before. The conventional ending obviously decreed the renunciation of the Amazonian life-style and the return into the patriarchal fold.

And Women, here divest

Your selves of Arms with me. [...]

And let your conquests henceforth be to love,

And give Men sole supremacy [...]. (1671, Act 5, Scene 1) 
All the Queen of Amazons is good for in the epilogue is comically to threaten the critics who might 'damn our Play' (Epilogue). In much the same way, in Pordage's The Siege of Babylon (1678) an Amazon who committed heroic deeds in battle and disdained love in favour of glory and fame is won over to marriage and a traditional gender role for herself and all her compatriots. A mythologized homage to Cupid is used to justify her capitulation and to naturalize the traditional gender roles: 'What Mortal dares, with mighty Love contend [...] (1678, Act 5, Scene 2)

Though 'classic' Amazons are generally armed with bow and arrows and dress up in an armour during battle, they do not necessarily wear male clothes all the time, but are recognizable as women. The Amazon Queens in Howard's and Pordage's plays never try to pass themselves off as men. The eponymous heroine in Crown's Juliana, or Princess of Poland (1671) does not even wear Amazonian dress and still leads a squadron into war and is, like her female court ladies, armed - a fact that only the villainous cardinal ridicules.

The women arm'd! then sure w'are all mistaken;

This preparation's only made

For some great Masquerade. (1671, Act 3, Scene 2)

Crown, however, is at paints also to assure us of Juliana's femininity by making her swoon and yield to the overpowering emotion of love in the end.

In plays featuring women in male disguise ${ }^{1}$ the relationship between the lovers is often charged with homoerotic overtones. In plays like Loves Cure, The Conquest of China by the Tartars, and Friendship Improv'd men feel passionately attracted to their supposedly male companions, while rejecting the advances of women. The issue is solved, of course, because the boys turn out to be cross-dressed women after all, so that the excess of male emotion can be explained away as an instinctive attraction to the opposite sex. The fervour of their declarations of love, however, is remarkable: ${ }^{2}$

I love you with a Fondness far above

All that was ever known in Woman's love.

My Friend-Oh! whither would my Transport tend?

Can I say more than what I say? my Friend! (Hopkins, 1700, Act 1)

\footnotetext{
${ }^{1}$ The phenomenon applies not only to Amazons but also to other adventurous girls disguised as men. Think, for instance, of Behn's The Younger Brother, Southerne's Sir Anthony Love or Farquhar's The Recruiting Officer.

${ }^{2} \mathrm{Cf}$ also:

His looks disarm me, and my Rage divert:

I've a desire to vanquish, but not hurt.

Sure some Divinity restrains my will:

He's th'only man I'de Conquer, but not Kill. (Settle, 1676, Act 3, Scene 1)
} 
Androgynous figures ${ }^{1}$ like the Amazons also raise the question whether femininity and masculinity are inborn qualities or the products of education. Seventeenth century attitudes to this problem were ambiguous. On the one hand, 'masculinity and femininity of soul were thought capable of existing in people irrespective of their biological definition' (Shepherd, 1981, 35). On the other hand, there was also the belief that biology determines behaviour, that women and men are by nature womanly and manly, and that one can no more change one's innate behaviour than one's genitals (Shepherd, 1981, 91). Beaumont and Fletcher's Loves Cure or The Martial Maid (1647 but first performed possibly in 1606) dramatises this question since it features siblings reared in ways atypical of their sex and portrays the difficulties both have with fitting into their proper gender roles. 'Custome hath turn'd nature topsie-turvy in you' (1647, Act 2, Scene 2). To be sure, they, too, are in the end converted to socially acceptable rules of conduct by love, but before that they scandalize their surroundings by the boy's effeminacy and the girl's aggression, which puts off even her suitor, who is afraid of becoming a hen-pecked husband. Most dramatists, however, come down much more clearly on the side of nature, not nurture. Pugnacity is generally regarded as unnatural in a woman, who ought to kill with her eyes, not with her sword.

Even plays assuming a basically positive attitude towards martial women thus view them as aberrations of nature and as exotic phenomena which do not fit into civilized society. Several plays, however, are much more hostile. Though a British national heroine, Fletcher's Queen Bonduca (1647, first performed 1611-1614) is unfit for war - much too self-assured and a bad strategian -, and her daughters exploit their sexuality to entrap the Roman enemies. This picture remains basically intact in Powell's 1696 version of the tragedy, where the treachery of the daughters is omitted but it is again made clear that Bonduca ought not to meddle in the affairs of men. In both plays, the Queen only gains heroic status by her defiance of her enemies in death. In parenthesis, it should be mentioned that in another Boadicea play one year later (1697), Hopkins turned heroic tragedy -which was going out of fashion - into pathetic tragedy, painting the Queen and her daughters as examples of virtue in distress dishonoured by a villainous Roman rapist, not as Amazons at all, though they gain everyone's admiration by their heroic deaths. Similarly, the patriotic women helping to free their mother-country in Trotter's Revolution of Sweden (1706) are afraid of fighting and anything but Amazons.

Even more openly misogynist than the Bonduca plays are a number of comedies depicting Amazons as foolish, quarrelsome and lecherous. Cartwright's The Lady Errant (1651) is a satire on female self-government and paints a ridiculous picture of man-hating women trying to shake off the yoke of female submission. A particularly absurd specimen is the eponymous heroine, who assumes the role of a hero destined to rescue men in distress. It is

\footnotetext{
${ }^{1}$ Nünning $(1991,31)$ suggests that this widening of traditional gender attributes for both men and women and the partial adoption of the other gender's attitudes and forms of behaviour anticipates Woolf's concept of androgyny.
} 
significant that the only likeable woman character subverts the feminist utopia of empowerment and self-government by persuading this stupid and boastful female knight to aide not the women but the men - since they are clearly in distress. The play ends with the feminist schemes thwarted and discredited and power put back into male hands.

The unruliness and insubordination of women is also thematized in plays like The Female Rebellion (written in 1657 by H.B., but only published in 1872), where a group of Amazons plot to kill their virtuous queen, but prove their total disqualification for government by constantly quarreling with one another.

In Fletcher and Massinger's The Sea Voyage (printed in 1647, but probably first performed in 1622) the women become Amazons by necessity only, because they are shipwrecked on a lonely island, but in fact loathe their celebacy and lust for men. Their loose behaviour disgusts even the weathered sailors cast away on the island:

Mast. [...] I had rather serve hogs, there's more delight in't Your greedy appetites are never satisfied; [...]

Tib. I am bad enough

And in my nature a notorious wencher;

And yet you make me blush at your immodesty. (1647, Act 4, Scene 1)

D'Urfey's Restoration rewriting, The Commonwealth of Women (1686), adds to this plot social satire, by detailing the menial tasks the men are set to perform, such as washing in a tub or minding a pet monkey. Both comedies enact male castration fears. The warning of the old 'protectress' against the tyranny of men and subjection of women is discredited and completely backstaged by these excesses. Besides, she is happy to revert to her wifely role as soon as her long-lost husband reappears.

Apart from these hostile visions, there are also a few humorous portraits of Amazons - such as Jasper Mayne's The Amorous Warre (1648 but possibly also first performed in the earlier decades of the century), where women merely disguise as Amazons to test the faithfulness of their lovers and husbands, who are unduly obsessed with the sex life of the supposed Amazons and end up sleeping with their own wives. Comic examples of contemporaneous Amazons are, for instance, Middleton and Dekker's Roaring Girle (1611), who wears male clothes, dexterously wields a sword and humiliates braggarts, or Shadwell's The Woman Captain (1680), who revenges herself on her tyrannical husband by exercising and beating him up in the guise of a military officer. Knight (140) has called Southerne's Sir Anthony Love (1691) 'the culmination of the seventeenth century's fascination with the bisexual.' The heroine is motivated by a Hobbsian desire for power (Morris, 1972, 5), plays the libertine and acquires a reputation for fighting. She denies her sex and completely identifies with the male role. 
When we survey the plays about Amazons discussed, there are three periods in the later $17^{\text {th }}$ century when a greater number of Amazonian plays were published: the middle of the century, the 1670s and the turn of the century. Salmonson $(1991,158 f$.) suggests that images of Amazons flourished in the 1640s because of the civil war in Britain and the fact that in France queens participated in government. However, many of the mid-century plays had already been performed earlier and were only printed at that time, so that figures like Queen Christina of Sweden (1626-1689), renowned for her masculine behaviour and cross-dressing, and Queen Henrietta Maria, wife of Charles I, who marched to Oxford with a loyalist army during the civil war, cannot have served as role models for the characters, though their heroic exploits may have rekindled interest in the figure of the Amazon. Works written in the 1650s and 1660s are indicative of the fashion for heroic drama and, but for one exception (The Lady Errant), paint positive pictures of martial women, as do all the plays I found from the 1670s. By that time, the early enthusiasm for Charles II had largely worn off in view of his policies, thus in spite of Buckingham's satire of the genre in The Rehearsal (1671) there may have been a nostalgic return to earlier values of chivalry. The plays at the end of the $17^{\text {th }}$ century are a mixed bag of positive, negative and humorous presentations, which it is difficult to relate to the cultural and political background. ${ }^{1}$ Several of them rewrite earlier plays and thus say less about the attitude to Amazons at the time and more about the Restoration custom of plundering Jacobean plays for adaptation. In any case, the revived interest in these female warriors was short-lived, since in the eighteenth century such plays were going out of fashion.

\section{Works Cited}

\section{Primary Texts}

Beaumont, F. \& J. Fletcher (1647). Love's Cure, or the Martial Maid. Available at http://gateway.proquest.com/openurl?ctx_ver=Z39.88-2003\&xri:pqil:res_ver= 0.2\&res_id=xri:ilcs\&rft_id=xri:ilcs:ft:drama:Z000056146:0 [6 November 2013].

Behn, A. (1683). The Young King. Available at http://gateway.proquest.com/openurl? ctx_ver=Z39.88-2003\&xri:pqil:res_ver=0.2\&res_id=xri:ilcs\&rft_id=xri:ilcs:ft: drama:Z000056842:0 [6 November 2013].

Crown, J. (1671). Juliana. Available at http://gateway.proquest.com/openurl?ctx_ver $=$ Z39.88-2003\&xri:pqil:res_ver=0.2\&res_id=xri:ilcs\&rft_id=xri:ilcs:ft:drama:Z 0 00069502:0 [6 November 2013].

\footnotetext{
${ }^{1}$ Settle at that time probably sided with Rochester and the court party, though it is difficult to guess his real allegiance ('Elkanah Settle', 2013). Crowne was a member of the court party satirizing the Whigs, though his family had received land grant from Cromwell ('John Crowne', 2013). Pordage may have been a royalist as well, since his father was reinstated into his parish after the Restoration ('Samuel Pordage', 2013). Edward Howard, brother of Sir Robert Howard, came from a royalist family and had the reputation of a literary fop (Harbage, 1936, 245).
} 
D'Avenant, W. (1663). The siege of Rhodes, part $i$. Available at http://gateway.proque st.com/openurl?ctx_ver=Z39.88-2003\&xri:pqil:res_ver=0.2\&res_id=xri:ilcs\&rft _id=xri:ilcs:ft:drama:Z000072391:0 [6 November 2013].

Dekker, T. \& T. Middleton (1611). The Roaring Girle. Available at http://gateway. proquest.com/openurl?ctx_ver=Z39.88-2003\&xri:pqil:res_ver=0.2\&res_id=xri:I lcs\&rft_id=xri:ilcs:ft:drama:Z000073034:0 [6 November 2013].

Fane, F. (1686). The sacrifice. Available at http://gateway.proquest.com/openurl?c tx_ver=Z39.88-2003\&xri:pqil:res_ver=0.2\&res_id=xri:ilcs\&rft_id=xri:ilcs:ft:dra ma:Z000076540:0 [6 November 2013].

Fletcher, J. \& P. Massinger (1647). The Sea Voyage. Available at http://gateway.proq uest.com/openurl?ctx_ver=Z39.88-2003\&xri:pqil:res_ver=0.2\&res_id=xri:ilcs\& rft_id=xri:ilcs:ft:drama:Z000079617:0 [6 November 2013].

Heywood, T. (1632). The iron age, part ii. Available at http://gateway.proquest.com/ o penurl?ctx_ver=Z39.88-2003\&xri:pqil:res_ver=0.2\&res_id=xri:ilcs\&rft_id=xri: ilcs:ft:drama:Z000086043:0 [6 November 2013].

Hopkins, C. (1700). Friendship improv'd: Or, the Female Warriour. Available at http://gateway.proquest.com/openurl?ctx_ver=Z39.88-2003\&xri:pqil:res_ver=0 $.2 \&$ res_id=xri:ilcs\&rft_id=xri:ilcs:ft:drama:Z000089052:0 [6 November 2013].

Hopkins, C. (1696). Neglected Virtue. Available at http://gateway.proquest.com/ openurl?ctx_ver=Z39.88-2003\&xri:pqil:res_ver=0.2\&res_id=xri:ilcs\&rft_id= xri: ilcs:ft:drama:Z000089063:0 [6 November 2013].

Howard, E. (1671). The womens conquest. Available at http://gateway.proquest.com/ openurl?ctx_ver=Z39.88-2003\&xri:pqil:res_ver=0.2\&res_id=xri:ilcs\&rft_id=xri: ilcs:ft:drama:Z000089319:0 [6 November 2013].

Pordage, S. (1678). The siege of Babylon. Available at http://gateway.proquest.com/ openurl?ctx_ver=Z39.88-2003\&xri:pqil:res_ver=0.2\&res_id=xri:ilcs\&rft_id=xri: ilcs:ft:drama:Z000111631:0 [6 November 2013].

Settle, E. (1676). The conquest of China by the Tartars. Available at http://gate way.proquest.com/openurl?ctx_ver=Z39.88-2003\&xri:pqil:res_ver=0.2\&res_id= xri:ilcs\&rft_id=xri:ilcs:ft:drama:Z000117531:0 [6 November 2013].

Secondary Sources

Davis, N.Z. (1991). 'Frauen, Politik und Macht.' In: A. Farge \& N.Z. Davis (ed.), Frühe Neuzeit, 189-206. Frankfurt: Campus Verlag. [In German].

Dixon, A. (ed.) (2002). Women Who Ruled. Queens, Goddesses, Amazons in Renaissance and Baroque Art. Ann Arbor: Univ. of Michigan Museum of Art.

'Edward Howard (playwright)' (2012). Wikipedia. Available at http://en.wikipedia. org/wiki/Edward_Howard_\%28playwright\%29 [6 November 2013].

'Elkanah Settle' (2013) Wikipedia. Available at http://en.wikipedia.org/wiki/Elka nah_Settle [6 November 2013].

Harbage, A. (1936). Cavalier Drama. New York: Modern Language Association of America.

Hughes, D. (2004). 'Aphra Behn and the Restoration Theatre.' In: Todd, J. \& D. Hughes (ed.), The Cambridge Companion to Aphra Behn, 29-45. Cambridge: Cambridge University Press.

'John Crowne' (2013). Wikipedia. Available at http://en.wikipedia.org/wiki/John_ Crowne [6 November 2013].

Knight, W. (1962). The Golden Labyrinth. A Study of British Drama. New York: Norton.

McDonald, M.L. (1976). Poetic Drama - Poetic Theory. Salzburg: Salzburg Studies. 
Morris, D.B. (1972). 'Language and Honor in "The Country Wife".' South Atlantic Bulletin 37(4): 3-10.

Nünning, A. (1991). 'Feministische Alternativen zur "erzwungenen Heirat". Die Dekonstruktion von Geschlechterstereotypen in Aphra Behns Komödien.' In: T. Fischer-Seidel (ed.), Frauen und Frauendarstellung in der englischen und amerikanischen Literatur, 9-31. Tübingen: Narr. [In German].

Salmonson, J.A. (1991). The Encyclopedia of Amazons. Women Warriors from Antiquity to the Modern Era. New York: Paragon House.

'Samuel Pordage' (2013). Wikipedia. Available at http://en.wikipedia.org/wiki/Samuel _Pordage [6 November 2013].

Shepherd, S. (1981). Amazons and Warrior Women. Varieties of Feminism in Seventeenth-Century Drama. Brighton: Harvester. 
